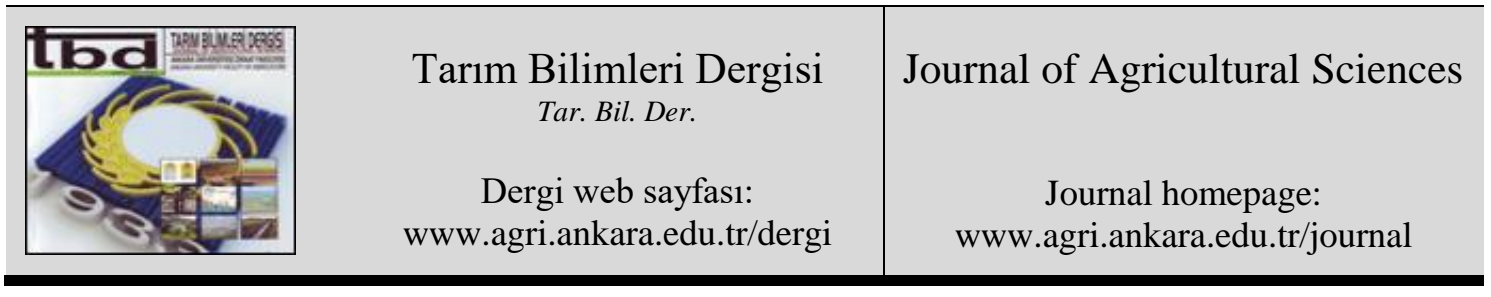

\title{
Antibacterial Effect of Bacteriocinogenic Enterococci from Different Sources on Listeria monocytogenes
}

\author{
Emel UNAL TURHAN ${ }^{a}$, Zerrin ERGINKAYA ${ }^{b}$, Alin BAYRAM TUREMIS ${ }^{b}$, Mevhibe TERKURAN ${ }^{b}$ \\ ${ }^{a}$ Osmaniye Korkut Ata University, Kadirli Applied Sciences School, Department of Food Technology, Osmaniye, TURKEY \\ ${ }^{b}$ University of Cukurova, Faculty of Agriculture, Department of Food Engineering, Adana, TURKEY
}

\section{ARTICLE INFO}

Research Article

Corresponding Author: Emel UNAL TURHAN, E-mail: emelunalturhan@gmail.com, Tel: +90 (328) 8880090

Received: 27 July 2018, Received in Revised Form: 17 September 2018, Accepted: 17 December 2018

\section{AUTHORS ORCID ID}

(Emel UNAL TURHAN: 0000-0002-0284-574X), (Zerrin ERGINKAYA: 0000-0001-6208-2927), (Alin BAYRAM

TUREMIS: 0000-0002-8014-6012), (Mevhibe TERKURAN: 0000-0002-3150-459X)

\begin{abstract}
In this study, antimicrobial activity of partially purified enterocins and crude bacteriocins from Enterococcus isolates with different sources was investigated against Listeria monocytogenes by disk diffusion assay. Totally $70 \%$ of enterococcal isolates (Enterococcus faecalis and Enterococcus faecium from food and clinical sources) were found as potential bacteriocinogenic strains. Both of food and clinical enterococcal isolates also exhibited antimicrobial properties against L. monocytogenes. Additionally, the present study detected that inhibitory
\end{abstract}

activity was strain-specific. Both crude bacteriocins and partially purified enterocins from $E$. faecium isolates showed lower antimicrobial activity against L. monocytogenes than E. faecalis isolates. The inhibition diameters obtained with crude enterocins and partially purified enterocins were respectively ranging from $12.33 \mathrm{~mm}$ to $13.25 \mathrm{~mm}$ and from $8.66 \mathrm{~mm}$ to $9.25 \mathrm{~mm}$. Crude bacteriocins retained antibacterial activity after heat treatment except $120{ }^{\circ} \mathrm{C}$ and also remained functional at $\mathrm{pH}$ values between 3 and 11 . As a result, it was considered that enterocins could be benefit in heated and acidic or basic food products as biopreservative.

Keywords: Bacteriocin; Enterocin; Enterococcus spp.; Listeria monocytogenes

\section{Introduction}

(C) Ankara Üniversitesi Ziraat Fakültesi

Enterocin is novel bacteriocin produced by Enterococcus spp. and active against various pathogenic or food spoilage bacteria such as Listeria spp., Clostridium spp., Staphylococcus spp., Bacillus spp., Campylobacter spp. and Escherichia coli (Moreno et al 2003; Campos et al 2006; Javed et al 2010; Anandani \& Khan 2014; Nami et al 2015). Bacteriocinogenic Enterococci strains, mostly E. faecalis and E. faecium, are isolated from different sources including vegetables, mostly fermented foods (cheese, sausages and other meat products), gastrointestinal system and various clinical specimens like urine, skin swab, pus and blood (De Vuyst et al 2003; Theppangna et al 2007; Ogaki et al 2016).

In recent years, there has been an increased tendency to use and study natural additives, such as natural antimicrobials and antioxidants. For this reason, bacteriocins have attracted more and more great attention (Savadago et al 2004; Y1ldırım et al 2014; Ogaki et al 2016). The use of bacteriocins or bacteriocinogenic 
cultures seen as a useful biocontrol method in food preservation to decrease the growth of spoilage or pathogenic microorganisms (Nascimento et al 2010; Ogaki et al 2016). In general, many researchers focused on the effect of temperature, medium composition and $\mathrm{pH}$ in bacteriocin production, but there are insufficient information deal with effect of these factors on inhibitory activity of bacteriocins (Aymerich et al 2000; Meera \& Devi 2012). Also, while most of the papers on enterocins have related to bacteriocinogenic enterococci from food sources, less attention has been given to isolates from clinical origins. The isolation of novel bacteriocins will be beneficial (Ogaki et al 2016). L. monocytogenes was most sensitive indicator to enterocins among pathogenic bacteria (Aymerich et al 2000; Nascimento et al 2010; Nami et al 2015). Listeria monocytogenes is one of the most important foodborne pathogens and resistant to adverse conditions including a wide range of temperatures and $\mathrm{pH}$, high $\mathrm{NaCl}$, sodium nitrite and various disinfectants. The prevention of $L$. monocytogenes growth in foods is highly difficult due to its resistance (Aymerich et al 2000). Investigators have come up with this problem from L. monocytogenes by using bacteriocins and described a large number of antilisterial bacteriocins (Ennahar \& Deschamps 2000). Bacteriocins were mostly tested in meat and dairy product to inhibit L. monocytogenes. For example; enterocin from $E$. faecium DPC1146 had inhibitory effect on L. monocytogenes in milk. A drop in viable cell counts of L. monocytogenes in enterocin AS-48 added meat sausages was observed (Galvez et al 2008).

The aim of the present study was to isolate bacteriocinogenic enterococci from clinical and food sources and to evaluate the effect of temperature and $\mathrm{pH}$ on antibacterial activity of crude bacteriocins supernatant against L. monocytogenes.

\section{Material and Methods}

\subsection{Samples and bacterial strains}

In this study, enterococci strains identified before by VITEK-2 automated identification system in the University central laboratory were used. As seen in Table 1, a total of 20 enterococcal isolates were selected from clinical cases (5 of E. faecalis and 5 of E. faecium) and from foods (5 of E. faecalis and 5 of $E$. faecium). Enterococci strains isolated from food samples (white cheese, Tulum cheese, raw chicken meat, fermented sausages) were provided by Cukurova University, Food Engineering Department. Enterococcal isolates provided various clinical sources were collected from the Central Laboratory of Balcalı Hospital, Adana-Turkey during 2010-2011. All enterococcal isolates (food and clinical) were stored in Brain Hearth Infusion Broth (BHI-Fluka, Germany) including $10 \%$ sheep blood and $10 \%$ glycerol (v/v) at $-20{ }^{\circ} \mathrm{C}$. All enterococcal strains were subcultured twice prior to the experiments. Enterococci were grown in De Man, Rogosa and Sharpe broth (MRS broth; Merck, Darmstadt, Germany). Listeria monocytogenes ATCC7644 (Remel-USA) was used as indicator organism. L. monocytogenes was growth in BHI broth and stored at $20{ }^{\circ} \mathrm{C}$ in BHI broth supplemented with $20 \%$ (v/v) glycerol (Ogaki et al 2016).

\subsection{Antibacterial spectrum of partially purified bacteriocins from enterococcal isolates}

Enterocins were partially purified from food and clinically isolates of E. faecium and E. faecalis according to modificated method of Anandani \& Khan (2014), Moreno et al (2003), Savadago et al (2004) and Yildirım et al (2014). The enterococcal isolates were incubated for $48 \mathrm{~h}$ at $37^{\circ} \mathrm{C}$, in $250 \mathrm{~mL}$ MRS broth. After incubation, cells were removed by centrifugation $\left(10000 \mathrm{~g}\right.$ at $\left.4{ }^{\circ} \mathrm{C}, 20 \mathrm{~min}\right)$, and $\mathrm{pH}$ of the cell free culture supernatant (CFS) was adjusted to $\mathrm{pH} 6.5$ by the addition of $10 \mathrm{~N} \mathrm{NaOH}$ to exclude antimicrobial effect of organic acid. Then, CFS was filter-sterilized $(0.45 \mu \mathrm{m}$ membrane-Millipore, Carrigtwohill, Ireland). The final concentration of sterile suspension was adjusted to $40 \%$ saturation of ammonium sulphate by slowly adding, and shaken overnight at $4{ }^{\circ} \mathrm{C}$. The mixture was centrifuged $\left(13000 \mathrm{~g}\right.$ at $4{ }^{\circ} \mathrm{C}$, $45 \mathrm{~min}$ ) and after harvesting of the surface specimens and bottom pellets were performed resuspension in $10 \mathrm{~mL}$ sodium phosphate buffer $(10 \mathrm{mM}, \mathrm{pH} 7)$. One volume of this suspension was mixed with 15 volumes of a methanol-chloroform $(1: 2, \mathrm{v} / \mathrm{v})$ and then extraction of this mixture was performed at $4{ }^{\circ} \mathrm{C}$ for $1 \mathrm{~h}$. The sample was centrifuged $\left(15500 \mathrm{~g}, 4^{\circ} \mathrm{C}, 30 \mathrm{~min}\right)$, the supernatant fraction decanted and the pellet air-dried. After resuspension of the pellet with $10 \mathrm{~mL}$ of ultrapure water (MilliQ; Millipore N.V., Brussels, Belgium) partially purified bacteriocin was obtained and was stored at $-20^{\circ} \mathrm{C}$. 
After purification, the antibacterial activity of enterocin was analyzed on Mueller Hinton Agar by disk diffusion assay against L. monocytogenes as a target (indicator) strain with a bit modification of previous reports (Yamato et al 2003; Savadago et al 2004; Campos et al 2006; Zheng et al 2015; Khalkhali \& Mojgani 2017). Disk diffusion assay was used for detection of bacteriocin activity in enterococcal isolates. L. monocytogenes indicator strain at a $10^{6} \mathrm{cfu} \mathrm{mL}^{-1}$ concentration was spread on Mueller-Hinton agar (Oxoid, England). Then, $100 \mu \mathrm{L}$ portions of samples from enterococci were placed on paper disks (thick, 6 $\mathrm{mm}$, Oxoid, England), which had previously been placed on the agar plates. The plates were incubated at $37^{\circ} \mathrm{C}$, for $24 \mathrm{~h}$ and translucent halos in the bacterial lawn surrounding the disks showed antibacterial activity. Diameters of inhibition zone around the disks were measured in millimeters.

Table 1- Inhibition zones from CB and partially purified enterocins obtained from each enterococcal isolate (as mm)

\begin{tabular}{|c|c|c|c|c|}
\hline Code of samples & Origin of samples & Species of isolate & Partially purified enterocins & $C B$ \\
\hline $\mathrm{F} 1$ & Urfa cheese & E. faecalis & 8.00 & 12.00 \\
\hline $\mathrm{F} 2$ & Fermented sausages & E. faecalis & 10.00 & 12.00 \\
\hline F3 & Raw chicken meat & E. faecalis & 9.00 & 16.00 \\
\hline F4 & Raw chicken meat & E. faecalis & 0.00 & 0.00 \\
\hline F5 & Fermented sausages & E. faecalis & 10.00 & 12.00 \\
\hline F6 & Antep cheese & E. faecium & 10.00 & 14.00 \\
\hline F7 & Erzincan Tulum cheese & E. faecium & 0.00 & 0.00 \\
\hline F8 & Hatay cow cheese & E. faecium & 9.00 & 13.00 \\
\hline F9 & Kasseri cheese & E. faecium & 0.00 & 0.00 \\
\hline F10 & Fermented sausages & E. faecium & 8.00 & 10.00 \\
\hline $\mathrm{C} 1$ & Clinical origin & E. faecalis & 0.00 & 0.00 \\
\hline $\mathrm{C} 2$ & Clinical origin & E. faecalis & 11.00 & 12.00 \\
\hline $\mathrm{C} 3$ & Clinical origin & E. faecalis & 8.50 & 15.00 \\
\hline $\mathrm{C} 4$ & Clinical origin & E. faecalis & 8.00 & 12.00 \\
\hline $\mathrm{C} 5$ & Clinical origin & E. faecalis & 9.00 & 14.00 \\
\hline C6 & Clinical origin & E. faecium & 0.00 & 0.00 \\
\hline $\mathrm{C} 7$ & Clinical origin & E. faecium & 8.00 & 15.00 \\
\hline $\mathrm{C} 8$ & Clinical origin & E. faecium & 10.00 & 12.00 \\
\hline C9 & Clinical origin & E. faecium & 0.00 & 0.00 \\
\hline $\mathrm{C} 10$ & Clinical origin & E. faecium & 8.00 & 11.00 \\
\hline
\end{tabular}

CB: crude bacteriocins (sterile cell free supernatant at $\mathrm{pH}$ 7)

\subsection{Antibacterial spectrum of crude bacteriocins from bacteriocinogenic enterococcal isolates at different pH and temperature}

The overnight bacteriocinogenic cultures were centrifuged at $10000 \mathrm{~g}$ for $30 \mathrm{~min}$ at $4{ }^{\circ} \mathrm{C}$. Cell free supernatants (CFS) were adjusted to $\mathrm{pH} 6.5$ by the addition of $10 \mathrm{~N} \mathrm{NaOH}$ and sterilized by filtration through a $0.45 \mu \mathrm{m}$ membrane (Millipore, Carrigtwohill, Ireland). CFS was resuspended in $10 \mathrm{mM}$ sodium phosphate buffer (pH 7) (Nascimento et al 2010; Nami et al 2015; Khalkhali \& Mojgani 2017). This resuspended CFS ( $\mathrm{pH} 7$ ) was used as crude bacteriocins (CB) to detect antimicrobial spectrum of bacteriocinogenic cultures (Cintas et al 1998). The inhibitory spectrum of $\mathrm{CB}$ in different $\mathrm{pH}$ and temperature was studied by determining the antagonistic action of $\mathrm{CB}$, against indicator organism $\left(10^{6} \mathrm{cfu}\right.$ $\mathrm{mL}^{-1}$ ) by disk diffusion assay as mentioned above. The antibacterial activity was detected by measuring the clear zones around the disks containing CB. The clear inhibition zones were given in $\mathrm{mm}$. Thermal stability of bacteriocinogenic enterococci was determined by incubation of $\mathrm{CB}$ at $60^{\circ} \mathrm{C}, 70^{\circ} \mathrm{C}, 80^{\circ} \mathrm{C}, 90{ }^{\circ} \mathrm{C}, 110$ ${ }^{\circ} \mathrm{C}$, and $121^{\circ} \mathrm{C}$ for 15 minutes. After incubation, bacteriocin samples were cooled to $+4{ }^{\circ} \mathrm{C}($ Campos et al 2006; Javed et al 2010). CB exposured to heat treatment was tested for antibacterial activity as described above. The $\mathrm{pH}$ stability of bacteriocinogenic enterococci was assayed at $\mathrm{pH}$ values $3,5,7,9$, and $11 . \mathrm{pH}$ level was adjusted with addition of $4 \mathrm{~N} \mathrm{HCl}$ or $4 \mathrm{~N} \mathrm{NaOH}$ to $\mathrm{CB}$. For each test, $50 \mathrm{~mL}$ of CB was mixed with $2 \mathrm{~mL}$ of sodium phosphate buffer $(10 \mathrm{mM})$ at each $\mathrm{pH}$, and samples were incubated at room temperature $\left(25^{\circ} \mathrm{C}\right)$ for $2 \mathrm{~h}$ (Franz et al 1997; Javed et al 2010). The antibacterial activity in each sample was determined as described above. 


\section{Results and Discussion}

Nowadays, there is a trend to detect novel enterocins from different origins due to their antimicrobial activity (Moreno et al 2003). Especially, it was focused on antilisterial activity of enterocins from $E$. faecium from various food such as meat products, fermented sausages, cheese (Ennahar \& Deschamps 2000; Aymerich et al 2000; Marekova et al 2003; Vimont et al 2017). In our study, enterocins from different origins were compared in view of their antibacterial activity against L. monocytogenes strain. Both clinical and foodborne enterococci that are used in this paper may be candidate strains for practical use. However there is a needed more information for distinction among enterocins (Moreno et al 2003). Therefore, bacteriocinogenic enterococcal strains should be carefully and individually assessed for their safety and associated risk factors (Khalkhali \& Mojgani 2017).

In this study, 20 strains of enterococci (10 E. faecalis and 10 E. faecium) from different sources were collected. Especially, E. faecalis and E. faecium were selected because pervious researchers reported that bacteriocinogenic strains are mostly belong to E. faecium and E. faecalis (De Vuyst et al 2003; Theppangna et al 2007; Özdemir et al 2011; Vimont et al 2017; Vijayakumar \& Muriana 2017). As observed in Table 1, eight of E. faecalis strains and six of E. faecium (totally $70 \%$ of strains) were bacteriocinogenic and the rest of strains (totally $20 \%$ of strains) did not produce any bacteriocin.

\subsection{Antibacterial activity of $C B$ and partially purified bacteriocins from bacteriocinogenic enterococci}

As seen in Table 2, both CB and partially purified bacteriocins had antibacterial effect on L. monocytogenes. Inhibition zones from $\mathrm{CB}$ varied from $12.33 \mathrm{~mm}$ to $13.25 \mathrm{~mm}$ whereas inhibition zones from enterocins were found between $8.66 \mathrm{~mm}$ and $9.25 \mathrm{~mm}$. When enterococcal strains were compared, CB and partially purified enterocins from $E$. faecalis had highest inhibition effect. Inhibition zones by $\mathrm{CB}$ and enterocin from $E$. faecalis were measured respectively as $13.12 \mathrm{~mm}$ and $9.18 \mathrm{~mm}$ in diameter. E. faecalis accounted for greater percentage $(57.14 \%)$ of antibacterial activity from the samples than E. faecium $(42.85 \%)$ as reported in Anandani \& Khan (2014). Similarly; De vuyst et al (2003) found that $58.7 \%$ of the E. faecium strains and $68.3 \%$ of the E. faecalis were bacteriocinogenic.

Table 2- The average of inhibition zones from CB and partially purified enterocins obtained from bacteriocinogenic enterococci (as $\mathbf{m m})$

\begin{tabular}{lcc}
\hline $\begin{array}{l}\text { Bacteriocinogenic } \\
\text { enterococcal isolates }\end{array}$ & $C B$ & $\begin{array}{c}\text { Partially purified } \\
\text { enterocins }\end{array}$ \\
\hline Food isolates & 12.71 & 9.14 \\
Clinical isolates & 13.00 & 8.92 \\
E. faecalis & 13.12 & 9.18 \\
E. faecium & 12.50 & 8.83 \\
E. faecalis from food isolates & 13.00 & 9.25 \\
E. faecium from food isolates & 12.33 & 9.00 \\
E. faecalis from clinical isolates & 13.25 & 9.12 \\
E. faecium from clinical isolates & 12.66 & 8.66 \\
\hline CB. crude bacteriocins & &
\end{tabular}

Antimicrobial effect of $\mathrm{CB}$ was found higher than partially purified enterocins. It was considered that presence of other inhibitory substances in CB caused additional antimicrobial activity (Zheng et al 2015). CB from clinical isolates led to higher inhibition than from food origin, while the opposite was observed for enterocin. As for isolate species, there are differences between antibacterial activity of isolate species (E. faecalis or E. faecium) and the effectiveness of the antibacterial activity of bacteriocinogenic enterococci is mostly relevant to the species. Klibi et al (2008) confirmed in our results that E. faecalis had higher antibacterial effect than E. faecium on L. monocytogenes. Generally, antimicrobial potential of enterococci was heterogeneous and strain-specific (Campos et al 2006; Nascimento et al 2010; Gómez et al 2012). 


\subsection{The effect of $\mathrm{pH}$ and temperature on antimicrobial activity of $\mathrm{CB}$ from bacteriocinogenic enterococci}

Antibacterial activity of $\mathrm{CB}$ at different $\mathrm{pH}$ and temperature were presented in Table 3. $\mathrm{CB}$ exhibited a broader $\mathrm{pH}$ and temperature range of activity against $L$. monocytogenes. The activity of $\mathrm{CB}$ against $L$. monocytogenes was maintained in all $\mathrm{pH}$ range (3-11) and temperature grades except $120^{\circ} \mathrm{C}$, depending on enterococci strains. Antibacterial activity of $\mathrm{CB}$ reached maximum levels at $\mathrm{pH} 7$ and $60{ }^{\circ} \mathrm{C} . \mathrm{CB}$ from E. faecalis was found more resistant to $\mathrm{pH}$ and temperature deviations than $E$. faecium. Reduction in activity of CB from E. faecalis and E. faecium at $110^{\circ} \mathrm{C}$ were found respectively at level of $26.30 \%$ and $20.97 \%$. Especially, bacteriocins have lost their activity after the exposure to thermal stress at $120{ }^{\circ} \mathrm{C}$ and any inhibition zones did not observed on plates.

Antibacterial activity of the enterocins depends on the $\mathrm{pH}$ and temperature (Moreno et al 2003). Antibacterial effects of $\mathrm{CB}$ from our isolates were investigated at various $\mathrm{pH}$ and thermal conditions. Significant differences were recorded in the $\mathrm{pH}$ and thermal stability of the studied enterocins in accordance with Khalkhali \& Mojgani (2017). As the temperature grades subjected to bacteriocins was increased, the inhibition zone was decreased in diameter. These results confirmed previous reports referring that the inhibitory action of the bacteriocinogenic enterococci reduced as temperature grade increased (Moreno et al 2003; Yamato et al 2003; Zhou et al 2014; Khalkhali \& Mojgani 2017). These bacteriocinogenic enterococci may be applied as biopreservatives for various food products subjected to heat treatment such as pasteurization, cooking, sterilization (Campos et al 2006). Ghrairi et al (2008) detected that enterocin MMT21 exposured to heat treatment at $100{ }^{\circ} \mathrm{C}$ for 15 minutes did not exhibit any inhibition effect against L. monocytogenes. Bilgin (2008) reported that heat treatment at $90{ }^{\circ} \mathrm{C}$ for 30 minutes retains activity of enterocin $\mathrm{HZ}$ whereas as temperature increased to $110^{\circ} \mathrm{C}$ and $121{ }^{\circ} \mathrm{C}$ for 15 minutes, a $50 \%$ and a $100 \%$ reduction in activity, respectively was observed. As seen our results, CB from E. faecalis strains were more resistant to increase in temperature grade than E. faecium. CB from clinical isolates was more sensitive to heat treatment than food isolates. Our results were confirmed by Uymaz (2009). Enterocins have mostly maintained inhibition effect both acidic and basic $\mathrm{pH}$ (Uymaz 2009). In general, they maintain their activity at diverse $\mathrm{pH}$ values between $\mathrm{pH} 4$ and $\mathrm{pH} 8$ (Ennnahar et al 1998). Ghrair et al (2008), enterocin produced by E. faecium MMT21 isolated from Tunisian Rigouta cheese had inhibitor effect on L. monocytogenes at $\mathrm{pH}$ between 2-10. Similarly, in our study, CB has continued its activity at $\mathrm{pH}$ ranging from 3 to 11. However, level of antibacterial activity of $\mathrm{CB}$ changed according to $\mathrm{pH}$ and highest inhibition effect was observed at $\mathrm{pH}$ 7. Antibacterial activity of bacteriocins gradually subsided as the $\mathrm{pH}$ values became more and more acidic or basic (Ennahar \& Deschamps 2000; Javed et al 2010; Zhou et al 2014). As a matter of fact, the present study detected that there are a drop in activity of CB at high and low $\mathrm{pH}$. Similar results were reported by various researchers: Bilgin (2008) stated that enterocin HZ by E. faecium obtained from local white cheese protect its activity in the range of $\mathrm{pH} 2-9$, while half of its activity at $\mathrm{pH} 10$, the majority of its activity at $\mathrm{pH} 11$ and totally of inhibition activity at $\mathrm{pH} 12$ was lost. Line et al (2008) reported that enterocin was active between $\mathrm{pH} 5.0$ and 8.7 except $\mathrm{pH} 3.0$ and above $\mathrm{pH} 9.5$.

Table 3- The average of inhibition zones from crude bacteriocin (CB) obtained from bacteriocinogenic enterococci at different $\mathrm{pH}$ and temperature (as $\mathbf{~ m m}$ )

\begin{tabular}{|c|c|c|c|c|c|c|c|c|c|c|c|}
\hline & \multicolumn{6}{|c|}{ Temperatures $\left({ }^{\circ} \mathrm{C}\right)$} & \multicolumn{5}{|c|}{ Acidity } \\
\hline $\begin{array}{l}\text { Bacteriocinogenic } \\
\text { enterococcal isolates }\end{array}$ & 60 & 70 & 80 & 90 & 110 & 120 & $p H 3$ & pH 5 & $p H 7$ & pH 9 & pH 11 \\
\hline Food isolates & 12.54 & 12.25 & 11.54 & 11.17 & 10.04 & 0.00 & 9.88 & 10.46 & 12.71 & 9.25 & 9.13 \\
\hline Clinical isolates & 11.96 & 11.42 & 10.92 & 9.96 & 9.50 & 0.00 & 9.50 & 9.75 & 13.00 & 11.42 & 10.38 \\
\hline E. faecalis & 12.29 & 11.75 & 11.42 & 10.79 & 9.67 & 0.00 & 10.00 & 10.33 & 13.12 & 10.25 & 9.88 \\
\hline E. faecium & 12.21 & 11.92 & 11.04 & 10.33 & 9.88 & 0.00 & 9.38 & 9.88 & 12.50 & 10.42 & 9.63 \\
\hline E. faecalis from food isolates & 12.33 & 12.00 & 11.33 & 11.33 & 9.33 & 0.00 & 10.00 & 10.67 & 13.00 & 9.00 & 9.00 \\
\hline E. faecium from food isolates & 12.75 & 12.50 & 11.75 & 11.00 & 10.75 & 0.00 & 9.75 & 10.25 & 12.33 & 9.50 & 9.25 \\
\hline E. faecalis from clinical isolates & 12.25 & 11.50 & 11.50 & 10.25 & 10.00 & 0.00 & 10.00 & 10.00 & 13.25 & 11.50 & 10.75 \\
\hline E. faecium from clinical isolates & 11.67 & 11.33 & 10.33 & 9.67 & 9.00 & 0.00 & 9.00 & 9.50 & 12.66 & 11.33 & 10.00 \\
\hline
\end{tabular}

Tarım Bilimleri Dergisi - Journal of Agricultural Sciences 26 (2020) 1-7 


\section{Conclusions}

The present work detected that food and clinical enterococcal isolates had ability to form bacteriocinogenic affect against $L$. monocytogenes. This research clearly suggests the potential usefulness of the bacteriocins obtained from E. faecalis and E. faecium at broad $\mathrm{pH}$ and temperature range. Nonetheless, the inhibitory action of the bacteriocinogenic enterococci reduced as temperature grade increased. Enterocins has mostly maintained inhibition effect at both acidic and basic $\mathrm{pH}$ values. Their activity is the highest at neutral $\mathrm{pH}$ levels. Enterocins from food and clinical sources have potential to use in food industry as biopreservatives against $L$. monocytogenes. However, the relationship between bacteriocin production, hemolysis, antibiotic resistance and the presence of virulence factors should be individually evaluated to control the safety and risk factors of bacteriocins from food and clinical sources. As a result, enterocin producer enterococcal strains that are safe and their enterocins may be used for food preservation.

\section{References}

Anandani J H \& Khan Z H (2014). Isolation, partial purification and biochemical characterization of enterocin producing enterococci. International Journal of Advanced Research 4(2): 18-20

Aymerich T, Garriga M, Ylla J, Vallier J, Monfort J M \& Hugas M (2000). Application of enterocins as biopreservatives against Listeria innocua in meat products. Journal of Food Protection 63(6): 721-726

Bilgin H (2008). Antibacterial activity of a bacteriocinogenic bacterium isolated from a fermented milk product. Master thesis, Gaziosmanpaşa University (Published), Graduate School of Natural and Applied Sciences, 53 pages, Tokat, Turkey

Campos C A, Rodriguez O, Calo-Mata P, Prado M \& Barros-Velazquez J (2006). Preliminary characterization of bacteriocins from Lactococcus lactis, Enterococcus faecium and Enterococcus mundtii strains isolated from turbot (Psettamaxima). Food Research International 39: 356-364

Cintas L M, Casaus P, Fernandez M F \& Hernandez H E (1998). Comparative antimicrobial activity of enterocin L50, pediocin PA-1, nisin A and lactocin S against spoilage and foodborne pathogenic bacteria. Food Microbiology 15: 289-298

De Vuyst L, Morenoa M R F \& Revets H (2003). Screening for enterocins and detection of hemolysin and vancomycin resistance in enterococci of different origins. International Journal of Food Microbiology 84: 299-318

Ennahar S \& Deschamps N (2000). Anti-Listeria effect of enterocin A, produced by cheese-isolated Enterococcus faecium EFM01, relative to other bacteriocins from lactic acid bacteria. Journal of Applied Microbiology 88: 449457

Franz C M A P, Toit M D, Holy A, Schillinger U \& Holzapfel W H (1997). Production of nisin-like bacteriocins by Lactococcus lactis strains isolated from vegetables. Journal of Basic Microbiology 37(3): 187-196

Galvez A, Lopez R L \& Abriouel H (2008). Application of bacteriocins in the control of foodborne pathogenic and spoilage bacteria. Critical Reviews in Biotechnology 28: 125-152

Ghrairi T, Free J, Berjeaud J M \& Manai M (2008). Purification and characterization of bacteriocin produced by Enterococcus faecium from Tunisian Rigouta Cheese. Food Control 19: 162-169

Gómez N C, Abriouel H, Grande M J, Pulido R P \& Gálvez A (2012). Effect of enterocin AS-8 in combination with biocides on planktonic and sessile Listeria monocytogenes. Food Microbiology 30: 51-58

Javed I, Ahmed S, Manam S, Riaz M, Ahmad B, Ali M I, Hameed A \& Chaudry G J (2010). Production, characterization, and antibacterial activity of a bacteriocin from newly isolated Enterococcus faecium IJ-31. Journal of Food Protection 73(1): 44-52

Khalkhali S \& Mojgani N (2017). Bacteriocinogenic potential and virulence traits of Enterococcus faecium and E. faecalis isolated from human milk. International Journal of Microbiology 9(4): 224-233 
Klibi N, Jouini A, Rojo-Bezares B, Masmoudi A, Ruiz-Larrea F, Boudabous A \& Torres C (2008). Phenotypic and genotypic characterization of bacteriocins in clinical enterococcal isolates of Tunisia. World Journal of Microbiology and Biotechnology 24: 653-657

Line J E, Svetoch E A, Eruslanov B V, Perelygin V V, Mitsevich E V, Mitsevich I P, Levchuk V P, Svetoch O E, Seal B S, Siragusa G R \& Stern N J (2008). Isolation and purification of enterocin e-760 with broad antibacterial activity against gram-positive and gram-negative bacteria. Antibacterial Agents Chromatography 52(3): 1094-1100

Marekova M, Laukova A, De Vuyst L, Skaugen M \& Nes I F (2003). Partial characterization of bacteriocins produced by environmental strain Enterococcus faecium EK13. Journal of Applied Microbiology 94: 523-530

Meera N S \& Devi M C (2012). Partial characterization and optimization of parameters for bacteriocin production by probiotic lactic acid bacteria. Journal of Microbiology and Biotechnology Research 2(2): 357-365

Moreno M R F, Callewaert R, Devreese B, Van Beeumen J \& De Vuyst L (2003). Isolation and biochemical characterization of enterocins produced by enterococci from different sources. Journal of Applied Microbiology 94: 214-229

Nami Y, Haghshenas B, Haghshenas M \& Khosroushahi A Y (2015). Antibacterial activity and the presence of virulence factors and bacteriocin structural genes in Enterococcus faecium CM33 isolated from ewe colostrum. Frontier Microbiology 6(782): 1-10

Nascimento M S, Moreno I \& Kuaye A Y (2010). Antibacterial activity of Enterococcus faecium fair-E 198 against Gram-Positive pathogens. Brazilian Journal of Microbiology 41: 74-81

Ogaki M B, Rocha K R, Terra M R, Furlaneto M C \& Maia L F (2016). Screening of the enterocin-encoding genes and antibacterial activity in Enterococcus species. Journal of Microbiology and Biotechnology 26(6): 1026-1034

Özdemir G B, Oryaşın E, Bıyık H H, Özteber M \& Bozdoğan B (2011). Phenotypic and genotypic characterization of bacteriocins in enterococcal isolates of different sources. Indian Journal of Microbiology 51(2): 182-187

Savadago A, Ouattara C A T, Bassole I H N \& Traore A S (2004). Antibacterial activities of lactic acid bacteria strains isolated from Burkinofaso fermented milk. Pakistan Journal of Nutrition 3(3): 174-179

Theppangna W, Murase T, Tokumaru N, Chikumi H, Shimizu E \& Otsuki K (2007). Screening of the enterocin genes and antibacterial activity against pathogenic bacteria in enterococcus strains obtained from different origins. Journal of Veterinary Medicine Science 69(12): 1235-1239

Uymaz B (2009). Isolation and identification of probiotic lactobacilli originated from food and human and characterization of the ability of bacteriocin production. . PhD Thesis, Ankara Üniversitesi (Published), Graduate School of Natural and Applied Sciences, 146 pp, Ankara, Turkey

Vijayakumar P P \& Muriana P M (2017). Inhibition of Listeria monocytogenes on ready-to-eatmeats using bacteriocin mixtures based on mode-of-action. Foods 6(22): 1-13

Vimont A, Fernandez B, Hammami R, Ababsa A, Daba H \& Fliss I (2017). Bacteriocin-producing Enterococcus faecium lcw44: a high potential probiotic candidate from raw camel milk. Frontier Microbiology 8(865): 1-8

Yamato M, Ozaki K \& Ota F (2003). Partial purification and characterization of the bacteriocin produced by Lactobacillus acidophilus YIT0154. Microbiology Research 158: 169-172

Yildirim Z, İlk Y, Yildirim M, Tokatli K \& Öncül N (2014). Inhibitory effect of enterocin KP in combination with sublethal factors on Escherichia coli O157:H7 or Salmonella Typhimurium in BHI broth and UHT milk. Turkish Journal Biology 38: 412-419

Zhou F, Zhao H, Bai F, Dziugan P, Liu Y \& Zhang B (2014). Purification and characterization of the bacteriocin produced by Lactobacillus plantarum, isolated from Chinese pickle. Czech Journal Food Science 32(5): 430-436

Zheng W, Zhang Y, Lu H M, Li D T, Zhang Z L, Tang Z X \& Shi L E (2015). Antibacterial activity and safety evaluation of KQ2.6 isolated from Peacock feces. BMC Biotechnology 15(30): 1-8 